\title{
Impact of COVID-19's Pandemic on the Economy of Indonesia
}

\author{
Susilawati $^{1}$, Reinpal Falefi ${ }^{1}$, Agus Purwoko ${ }^{2}$ \\ ${ }^{1}$ Faculty of Public Health, State Islamic University of North Sumatra, Medan, Indonesia \\ ${ }^{2}$ Natural and Environmental Management Studies, University of North Sumatra, Medan, Indonesia \\ susilawati_skm@yahoo.co.id
}

\begin{abstract}
COVID-19 is a global health problem including in Indonesia. The increased case of COVID-19 proved to have quite a significant impact on the economy globally which may have affected stability in Indonesia. This method of collecting data is a method of study literature with secondary data types. Data is taken from the Internet with respect to the validity of information such as government official information, official online sites and processed results of valid data. After obtaining the existing reference, a sorting of information that is appropriate to the topic of discussion. Data analysis is presented in graphical form and comes with a descriptive narrative. Based on the research, the impact of COVID-19 pandemic affects the economy in Indonesia. The affected sectors during the COVID-19 pandemic are transportation, tourism, trade, health and other sectors, but the economic sector most affected by COVID-19 is the household sector. Optimizing the potential in the country, the decline of BI-7 Day Reverse Repo Rate (BI7DRR), the interest rate of Deposit facility, and Lending facility interest rate, monitoring of global and domestic economic development conducted by Indonesia was assessed precisely so that inflation and stability remain in control.
\end{abstract}

Keywords

impact; pandemic; Covid-19; economy; Indonesia

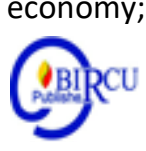

\section{Introduction}

COVID-19 is a global health problem including Indonesia. This was initiated from the information of the World Health Organization (WHO) on 31 December 2019 there was a case of a cluster of pneumonia with a new etiology in Wuhan City, Hubei Province, China and later expanded beyond China. On 30 January 2020, COVID-19 was set to become the public health Emergency of International Concern (PHEIC). On 11 March 2020, COVID-19 was designated as a pandemic. Indonesia first reported 2 positive cases on March 2, 2020 and a positive case continued to increase (Kementrian Kesehatan RI, 2020a). Until April 25, 2020, Indonesia already reported 8. 211 Positive cases, 689 cases died, 1.002 cases recovered from 50,563 people examined with the results of the examination is 42,352 negative (Kementrian Kesehatan RI, 2020b). 


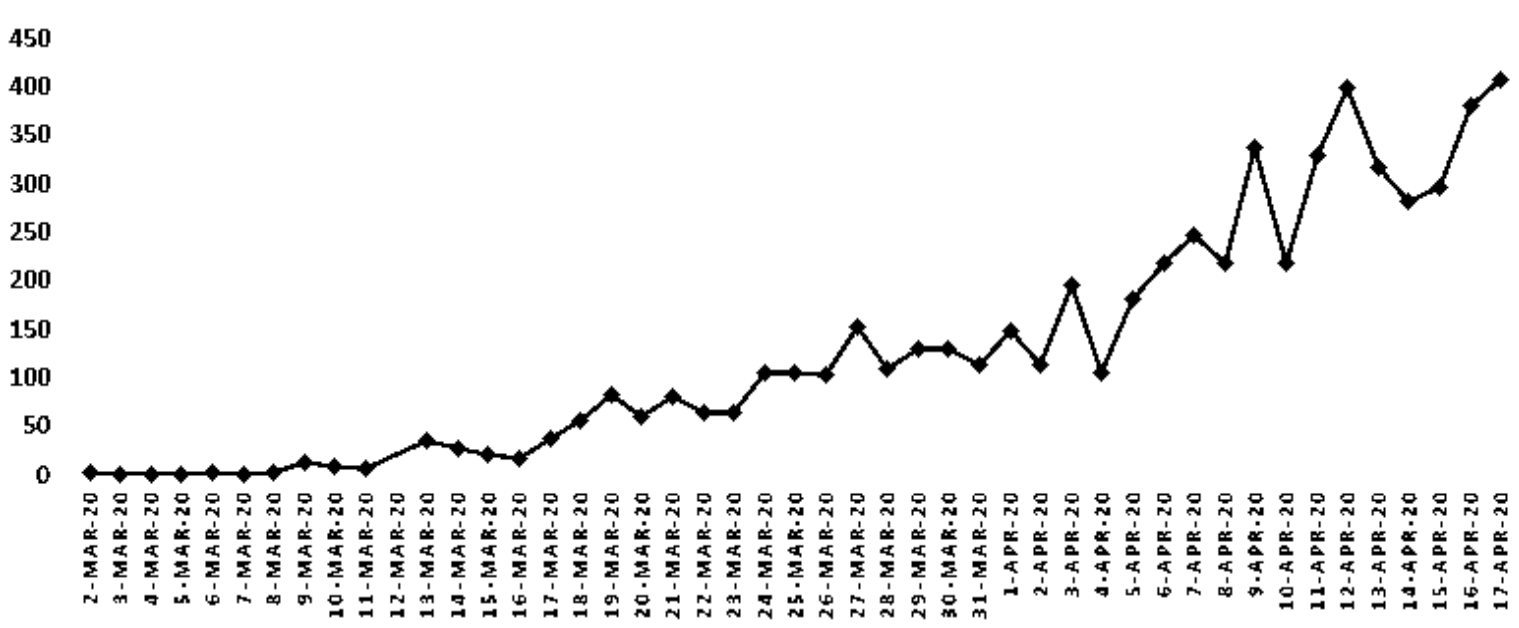

Figure 1. Trend Case Confirmation in Indonesia

The increased case of COVID-19 has affected the world economy including Indonesia. The COVID-19 pandemic that has been established by the UN, affects the transportation, tourism, trade, health and other sectors. The "lock down" policy is taken by various countries to prevent further spread of covid-19, so that economic activities are hindered and put pressure on the world's economic growth in the future including Indonesia's economic growth. The Government encourages the Ministry and institutions (K/L) as well as the local government (PEMDA) to accelerate spending primarily on the first quarter 2020 schedule. This was done to reduce the pressure on Indonesia's economic growth due to the pandemic Covid-19, as well as a decline in commodity prices (Kementerian Keuangan RI, 2020a).

The World Bank is projecting Indonesia's economic growth this year will be depressed at 2.1 percent. This is due to the continued widespread distribution of Covid-19 both domestically and abroad. Bank Indonesia (BI) has also revised the projected economic growth of the RI to under 5 percent or only about 2.5 percent. Pandemic Covid- 19 will have a bad implication for the world's economy and Indonesia this year, as it occurs along with declining commodity prices and financial market volatility. The relationship between inflation and economic growth is one of the debatable issue and the most important macroeconomic discussions among macro economists, policy-makers and monetary authorities in all countries (Wollie, 2018). Inflation that occurred in this year in the projection will be increased to 3 percent, because of the tight supply of food and depreciation of currencies that are expected to be offset partly by the decline in the price of non-subsidized fuels, as well as additional subsidies for electricity and food. However, in the year 2021 inflation is believed to return to normal levels, which is 2.8 percent. Which is usually able to grow to 5.02 percent. Meanwhile, in terms of inflation, tourism and commodity export revenues, there is an estimated decline that resulted in the current transaction deficit reaching 2.9 percent of the gross domestic product (GDP) in 2020 (Kementerian Keuangan RI, 2020a). According to A. Ademuyiwa (2019) when an economy is going through a persistent inflation, Gross Domestic Product (GDP) increases, this does not actually reflect the true growth in an economy. Hence, the rate of inflation must be subtracted from the GDP to get the real growth percentage, called the real GDP. 


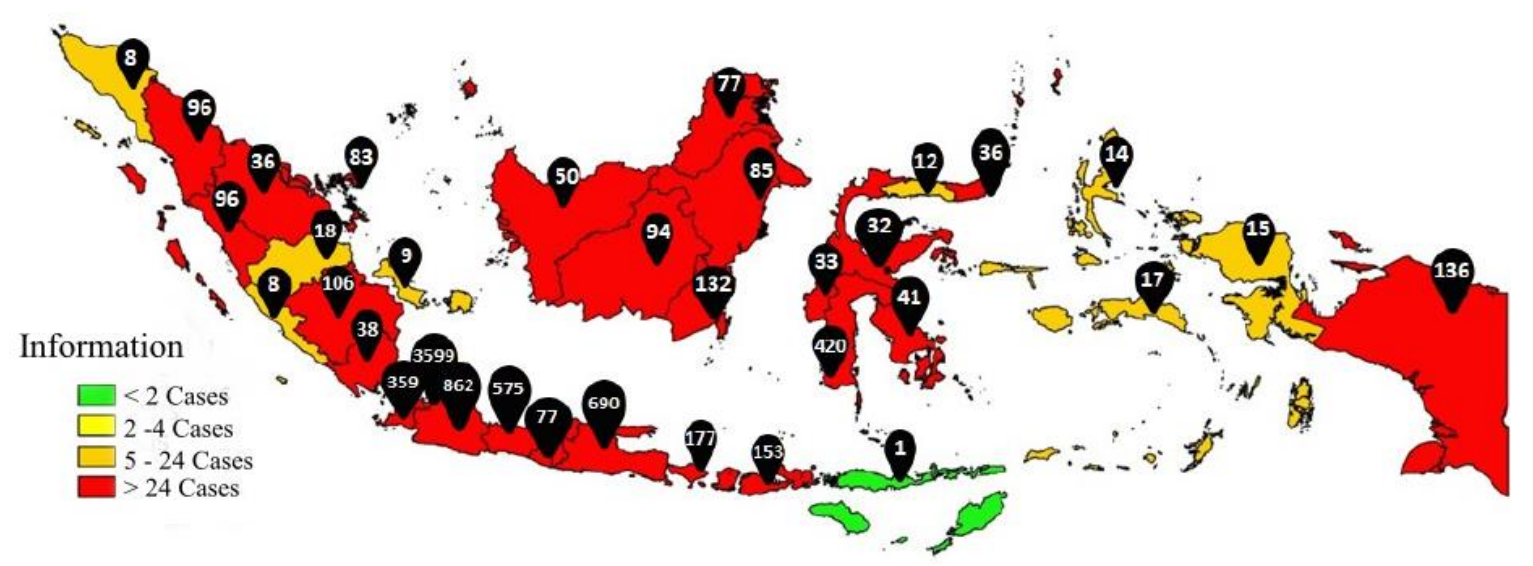

Figure 2. COVID-19 Spread in Indonesia

The government also conducts re-focusing budgeting and launches fiscal Stimulus Packages Vol I and vol II which are expected to support the real sector. In general, the current government's top priorities are support for the healthcare sector, strengthening social safety nets and salvage business sectors (Kementerian Keuangan RI, 2020a). However, for Indonesia, COVID-19 already has significant implications for the tourism sector, lowering export performance, economic growth performance. The most impactful main sectors are the accommodation sector, transportation, retail, and manufacturing of the current transaction balance deficit (CAD) (Media Indonesia, 2020).

If it is reviewed from the workers ' economy, it is based on the UN's Department of Economic and Social Affairs (UN-village), that millions of workers are at risk of losing jobs when nearly 100 countries close the national frontier in terms of a global economic contraction of 0.9 percent or higher at the end of 2020 (Surabaya Net, 2020). Therefore, the research aims to see the impact of the COVID-19 pandemic to the economy in Indonesia.

\section{Research Methods}

\subsection{Information Collection}

This method of collecting the research data uses the literature study method. The type of data collected is secondary data. Data extracted from online Media with data criteria are taken from official website Information of the Government of Indonesia, website official online news website, and processed data from relevant sources. The criteria of data that is not taken are personal website Information (blog), personal quotes of people (non-government), social media (Facebook, Instagram, Twitter, and other social media), and media chat. The range of information updates starts from February 2020 to May 2020. The Data collected comes from publications in Indonesia (online).

\subsection{Place and Time Research}

This research place is conducted in Medan City, North Sumatera Province, Indonesia. While the research time began in February 2020 until the month of May 2020.

\subsection{Information Processing}

After obtaining an existing reference, the sorting of information that corresponds to the topic of discussion is the impact of the COVID-19 pandemic to the economy in Indonesia, and then the processing of information according to the topic of discussion. 


\subsection{Information Analysis}

Based on the literature study conducted, data analysis presented in the form of graphs and equipped with a descriptive narrative related to the impact of the COVID-19 pandemic to the economy in Indonesia.

\section{Discussion}

Based on Manulife investment Management data, Indonesia is a country that has decreased interest rates, decreased major sectors such as tourism sector, aviation transportation, property, and social security as well as a GWM (mandatory Giro) decline (Manulife Investment Management, 2020).

TAIWAN (25 Feb)

USD2 billion stimulus

KOREA (17 Feb)

Stimulus USD356 million probability interest rate reduction

MALAYSIA $(27 \mathrm{Feb})$

USD4.7 billion stimulus $25 \mathrm{bps}$ interest rate reduction (to $2.75 \%$ )

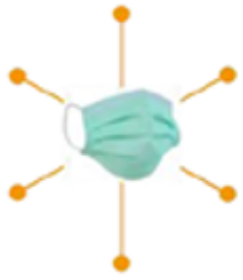

SINGAPORE (18 Feb)

SGD4 billion stimulus

THAILAND (4 Feb)

$25 \mathrm{bps}$ interest rate reduction (to $1.0 \%$ ) Stimulus package plan

INDONESIA $(25 \mathrm{Feb})$

$25 \mathrm{bps}$ interest rate reduction (to $4.75 \%$ )

IDR10 Trillion stimulus supports the tourism, aviation, property and social security sectors Reduction in foreign currency statutory reserves from $8 \%$ to $4 \%$ Decline in reserve requirement for banks conduction export-import activities

Figure 3. Fiscal and Monetary Policy Response - ASIA

Pandemic COVID-19 in Indonesia resulted in a potentially growing negative Indonesian economy of $0.4 \%$ which is the worst-case scenario. The optimal scenario is only $2.3 \%$. Reviewed from the growth of household consumption, growth scenarios were assessed to slow down, which was $3.2 \%$ in weight scenarios, and $1.6 \%$ in worst-case scenarios, and government consumption growth only grew $6.83 \%$ or worst case scenario of $3.73 \%$ (Kata Data, 2020b).

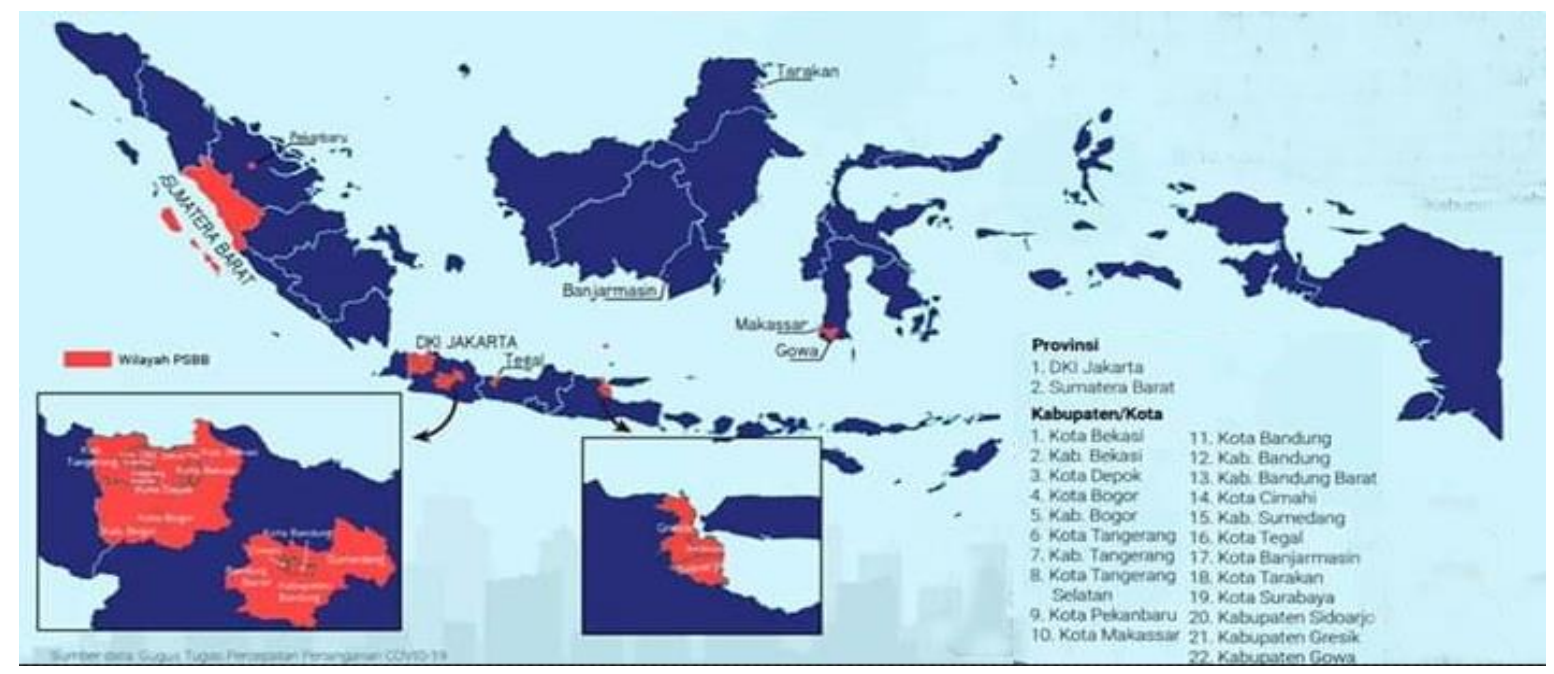

Figure 4. PSBB Distribution in Indonesia 
In areas that implement large-scale social restrictions (PSBB), it certainly has an impact on the economy. One of the areas that implement PSBB, namely Jakarta, is the calculation of the scenario so that the results gained that economic activity does not stop completely. About $75 \%$ stopped for 14 days in the worst scenario, thus having an implication of $-2.78 \%$ against gross Regional domestic product (PDRB), and a decrease in household income of $-2.77 \%$ (CNBC, 2020).

If reviewed from employment, it will impact on $1 \%$ termination of employment based on sector, trade, hotel, and restaurant, Transportation and communication, services, industry, electricity, gas, clean water and excavation and mining sectors. The result of termination of the relationship is predicted to affect $-0.8 \%$ economic growth (CNBC, 2020).

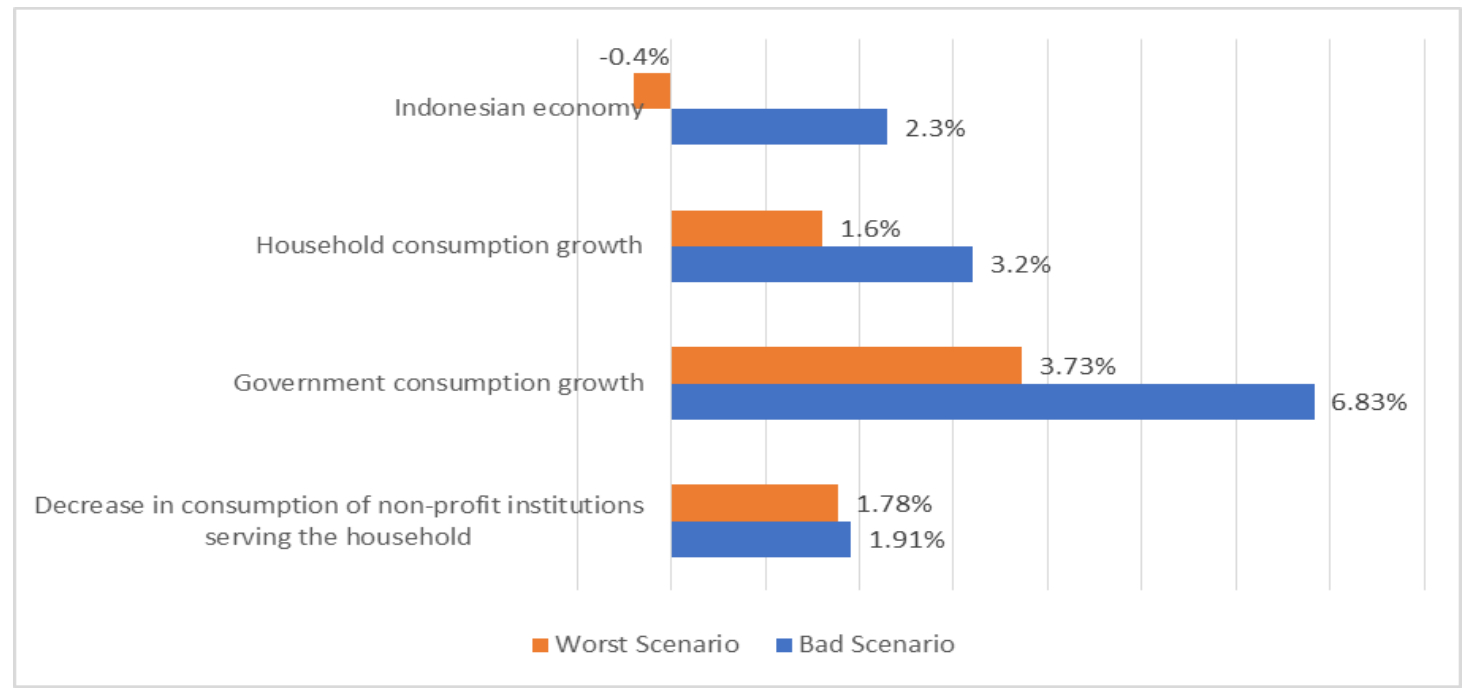

Figure 5. Growth Scenarios

On the consumption aspect of non-profit institutions that serve households, will decrease by $1.78 \%$ or worst-case scenario $1.91 \%$. The cause of the decline is a less positive investment (1\% growth) or an estimate of the largest decline of $4 \%$, export sector which decreased $14 \%$ to $15.6 \%$, and imports that dropped $14.5 \%$ to $16.65 \%$ (Kata Data, 2020b).

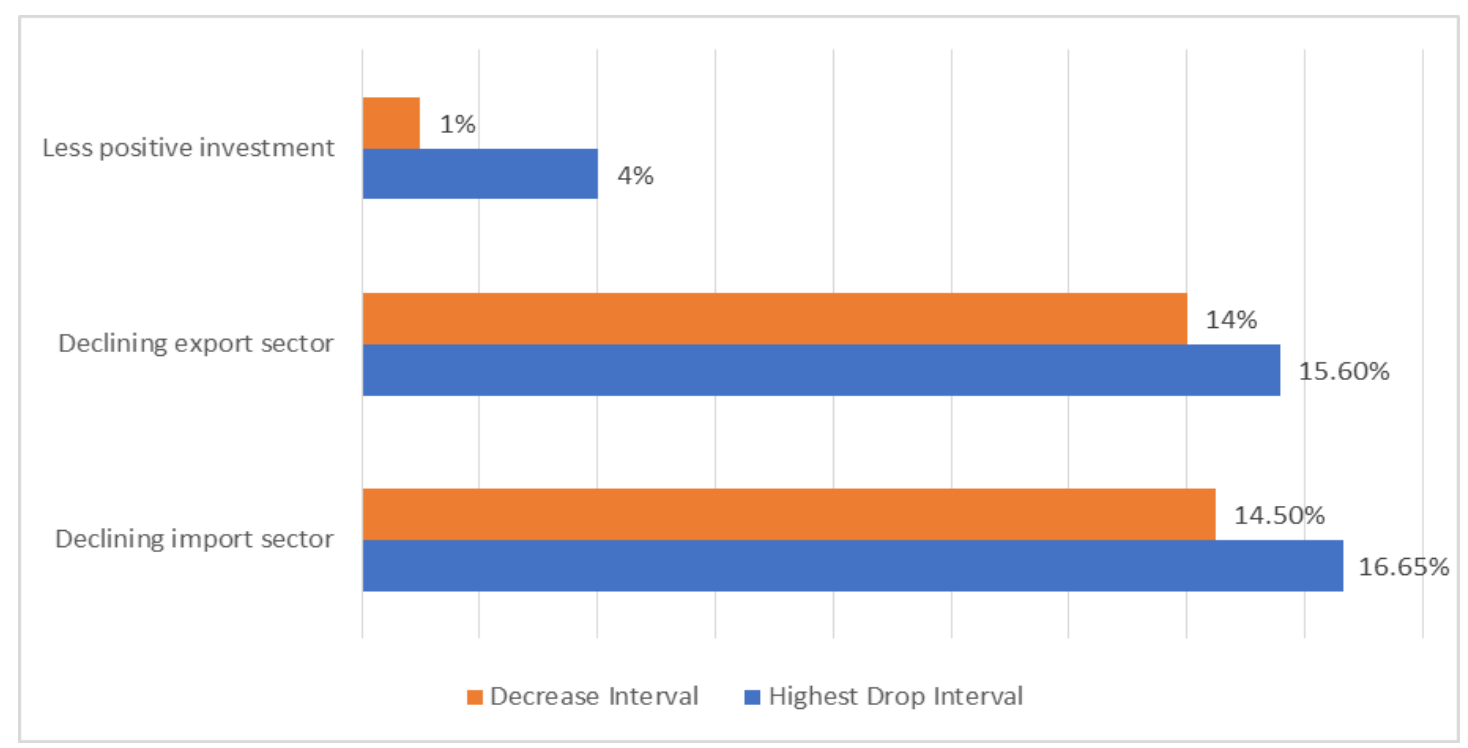

Figure 6. Cause of Decline 
Based on sectors that have impacted the impact of pandemic Covid-19, the household sector has been a very significant sector because it does not conduct economic activity, Small and Medium Enterprises (UMKM) and corporations become a sector affected and implication in the financial sector (Kata Data, 2020b).

In general, the impact of COVID-19 is quite significant to the Indonesian economy. The global economic throttling and manufacturing industry performance will have an impact on export performance in Indonesia. The decline in economic productivity (20 to 25 percent), which led to China's 5 percent economic growth, led to various conditions (CSIS Indonesia, 2020).

Table 1. Percentage of imports Indonesia from China 2018

\begin{tabular}{lc}
\hline Types of Goods/Products & Percentage (\%) \\
\hline Capital goods & 39.33 \\
\hline Semi-Finished goods & 23.14 \\
\hline Machine Parts and Components & 36.27 \\
\hline $\begin{array}{l}\text { Parts and components of office equipment and communication } \\
\text { devices }\end{array}$ & 29.05 \\
\hline - Parts and components of motor vehicles & 17.48 \\
\hline
\end{tabular}

Source: CSIS Indonesia

Source of raw materials or capital goods, of course, Indonesia need to find such sources from other countries even more expensive price. Optimizing the domestic potential is important to be done as a result of China's economic slowdown and is expected to be an alternative production center so as to contribute to global supply during COVID-19 pandemic. Indonesia steps such as the decline of BI-7 Day Reverse Repo Rate (BI7DRR), interest rate Deposit Facility, and Lending facility interest rate, monitoring of global and domestic economic development conducted by Indonesia are assessed precisely so that inflation and stability remain in control.

Indonesian Ministry of Finance noted at least eight losses caused by the outbreak of the virus. First, until 11 April more than 1.5 million employees broke down or termination of employment (LAYOFFS) and was formulated. Where 1.2 million workers came from the formal sector, 265,000 from the informal sector. Secondly, the Indonesian Purchasing Managers Index (PMI) below the 50 level is only 45.3 in March 2020. Thirdly, more than 12,703 flights at 15 airports were cancelled throughout January-February, with details of 11,680 domestic flights and 1,023 international flights. Fourth, around Rp 207 billion lost revenues in the air service sector, with approximately Rp 48 billion lost donated by China's flights. Fifth, tourist numbers decreased to 6,800 per day, especially tourists from China. Sixth, Indonesian Hotel and Restaurant Association estimates that declining occupancy rates around 6,000 hotels in Indonesia can reach 50\%. This could affect the decline of tourism foreign exchange more than half a year ago. Seventh, Indonesia's imports throughout January-March 2020 dropped 3.7\% year to date (YTD). Eighth, inflation in March 2020 recorded at $2.96 \%$ year on year (yoy) was donated by gold price increases in jewelry as well as some food prices soaring. However, there are deflation on various chili commodities and air freight rates (Santoso, 2020). 
Table 2. Economic Losses

\begin{tabular}{ll}
\hline Variable & \multicolumn{1}{c}{ Impact } \\
\hline Workers & 1.5 million workers experience a break \\
\hline Purchasing Managers Index (PMI) & Below level 50 \\
\hline Flight & $>12,703$ flights at 15 airports cancelled \\
\hline Air Service & Loss of revenue amounted to Rp 207 billion \\
\hline Tourist & Dropped drastically by 6,800 per day \\
\hline Hotel and Restaurant & Occurrence of decreased occupancy rate around \\
& 6,000 hotels in Indonesia reached 50\% \\
\hline Import & Down 3.7\% year to date (YTD) \\
\hline Inflation & Inflation of 2.96\% year on year (yoy) \\
\hline
\end{tabular}

Source: Kontan.co.id

The Government issued circular letter (SE) on 18 March 2020, all indoor and outdoor activities in all sectors relating to tourism and the creative economy were delayed temporarily in order to reduce the spread of Corona. This resulted in the tourism sector being paralyzed, so that unemployment is increasing because tourism is one of the containers that provide jobs for the community around the tourism area and outside society. It is not only a temporary paralysis of the tourism sector, but employees of other types of companies have experienced the impact of the Covid-19 pandemic. worker activity that is usually done outside the home directly forced to be done in the House, and there are many employees who are threatened by the termination of work rights (layoffs) because of the many jobs that are not possible to be done at home, as does the production activities that depend on the machine that is in the production place. The termination of this work is also done due to lack of purchase from consumers and dibatasinya exports to certain countries so that it will inhibit exports and reduce the company's revenue, even the company can suffer losses. There is also another cause of dismissing the employees because of the scarcity of raw materials to be produced imported from the outside country such as from China so that it will impede industrial activities. Companies that cease to operate and an increase in the number of unemployment rates can inhibit and reduce gross domestic product (GDP) and inhibit Indonesia's economic growth despite the policy being done, but there are still people who misuse this policy, such as learning activities and work at home in use for vacations outside the city. Thus, this policy can expand and accelerate the spread of Corona viruses, both from being disseminated by visitors to local communities, as well as disseminated by local communities to visitors.

Corona virus outbreak in China was also suspected to have an impact on Indonesian agricultural trade. During this time the export of palm oil is one of the largest export contributors to China. However, in February 2020, the realization only reached 84,000 tonnes. This figure is very far when compared with the previous month's realization of January 2020 of 487,000 tons and in the same period of 2019 that reached 371,000 tons (Detik.com, 2020).

In terms of the import of food, Indonesia, which has a dependence of garlic from China, can only import garlic from China for 23,000 tonnes by February 2020. This figure also drops drastically when compared with the previous year's imports reaching 583,000 tons (finance.detik.com, 17 February 2020). In February 2020, China's largest import decline was also seen on fruit commodities. The fruit commodity imports fell significantly by $78.88 \%$ from USD160,4 million to USD33,9 million (Kata Data, 2020a).

Since the outbreak of the Corona virus, in addition to enforcing the restriction policies of importing living animals from China, the government also stopped flights from and to China as of February 5, 2020. Which of course will also affect the Indonesian tourism sector. 
Many travel and flight companies suffer losses due to flight termination from and to China. Since the implementation, the number of Chinese tourists visit to Bali has decreased. In 2019, from 6.3 million foreign tourists, as many as 1,185,519 tourists or $18.2 \%$ were from China. However in January to mid-February 2020 noted 22,000 Chinese tourists cancel to Bali (Tribunnews, 2020). It greatly affects the economy of Bali province.

In February 2020, state acceptance showed an improvement from January 2020. Realization of state income and grants per end of February 2020 has reached Rp216,61 trillion or 9.70 percent of the target on the BUDGET 2020. The realization is supported by the tax receipt recorded as positive growth, which is growing by 0.3 percent. With such conditions, until the end of February 2020 the realization of taxation receipt recorded at Rp177,96 trillion or has reached 9.54 percent of the target stipulated in the state BUDGET, non-tax country acceptance (PNBP) reached Rp38,62 trillion (10.52 percent of the target), and grants amounting to RP0,03 trillion (5.73 percent of the target) (Kementerian Keuangan RI, 2020a).

The growth of tax revenues was driven by the growth of Earth and building tax revenues (PBB) and other taxes, each growing 95.00 percent (YoY) and 5.67 percent (YoY). For Nonmigas $\mathrm{PPh}$, the achievement of its acceptance is still supported by the acceptance of PPh 21 which grew by 10.08 percent, PPh 25/29 agency, and PPh Final. The realization of customs and excise receipts reached 11.22 percent of the target in the BUDGET of 2020 and was able to grow 51.52 percent (YoY). The actual realization of the acceptance is supported by the acceptance of excise and import duty (BM). The growth in its customs and excise acceptance is still derived from the recorded tax revenues of 89.20 percent (YoY) (Kementerian Keuangan RI, 2020a).

The realization of PNBP until the end of February 2020 reached Rp38,62 trillion or 10.52 percent of the target in the BUDGET 2020. The achievement of PNBP realization is mainly dominated by the realization of PNBP SDA and other PNBP, each amounting to RP Rp20,92 trillion and Rp15,98 trillion. The realization of the PNBP of SDA Migas (Natural resources of oil and Gas) Indonesian Crude Price (ICP) period from January to February 2020 recorded at USD61,00/barrel or higher USD2,07/barrel compared to the same period in the previous year of USD58,93/barrel(Kementerian Keuangan RI, 2020a).

\section{Government Roles}

The Indonesian Government has taken various measures through the social safety nets to help the people's economy affected by the COVID-19 either directly or indirectly. The step to break the COVID-19 deployment chain was judged to have an economic impact on the crowd. This means that the Government is seriously providing an economic stimulus package. The Government realized the true non-medical impact of the plague caused by the SARS-CoV-2 virus and can be seen from the many people who lost their jobs and livelihoods because they had to be home. Seeing the condition, the Government has made various efforts to help the Community economy through various policies. Policies that only rely on economic growth are policies that limit the circulation of assets among the rich people (Martinelli, 2019). Some of these policies include direct cash assistance (BLT) which uses the village fund. The BLT is budgeted to use a Rp22,47 trillion that is appropriated from the RP72 trillion estimated for the village fund. In addition, there is a "Prakerja's card" with a monthly incentive that reaches RP3, 5 million per person. Not only that the government has also launched an electricity tariff reduction of 50 percent for customers capacity of 450 watts over three months (Arifin, 2020).

Some of the steps to be taken are as follows: accelerating realization of Shopping ministries/institutions, especially social assistance spending ( $\mathrm{SUCH}$ as $\mathrm{PKH}$ and health), as 
well as non-operational shopping, Mendorong tourism centers through various support programs, such as the acceleration of development of five super-priority tourist destinations (Lake Toba, Borobudur, Likupang, Labuan The government will also set up fiscal and nonfiscal policies to stimulate the tourism sector, encourage and accelerating the labor-intensive spending on productive activities that absorb a lot of manpower, such as infrastructure shopping in the center and the region, are optimizing the role of the APBN as a flexible instrument in response to the economic situation (countercyclical) by staying within the limits of safe and restrained, accelerating development of the people's Business Credit (KUR) (Kementerian Keuangan RI, 2020b).

\section{Conclusion}

COVID-19 pandemic, in addition to being a global health problem, also has implications on the economy in Indonesia. Indonesia potentially grows negative $0.4 \%$ which is the worst-case scenario. The economic sector most affected by COVID-19 is the household sector. Optimizing the potential in the country, the decline of BI-7 Day Reverse Repo Rate (BI7DRR), the interest rate of Deposit facility, and Lending facility interest rate, monitoring of global and domestic economic development conducted by Indonesia was assessed precisely so that inflation and stability remain in control.

\section{References}

A. J. Ademuyiwa and A. A. Adetunji. (2019). Impact of Some Economic Variables on the Real Gross Domestic of Nigeria. Budapest International Research and Critics InstituteJournal (BIRCI-Journal), 12-19.

Arifin, D. (2020). Jaringan Pengaman Sosial Kurangi Dampak Ekonomi Masyarakat di Tengah Pandemi COVID-19. Retrieved May 3, 2020, from BNPB website: https://bnpb.go.id/berita/jaring-pengaman-sosial-kurangi-dampak-ekonomi-masyarakatdi-tengah-pandemi-covid19

CNBC. (2020). PSBB Berlaku per Hari ini, Apa Dampaknya ke Ekonomi Jakarta? Retrieved April 26, 2020, from https://www.cnbcindonesia.com/news/20200410061039-4151038/psbb-berlaku-per-hari-ini-apa-dampaknya-ke-ekonomi-jakarta

CSIS Indonesia. (2020). Mengukur Dampak COVID-19 pada Pertumbuhan Ekonomi dan Perdagangan Indonesia 2020. Jakarta.

Detik.com. (2020). Di Depan DPR, Mentan Ngeluh Ekspor-Impor Pangan Terganggu Corona. Retrieved May 3, 2020, from https://finance.detik.com/beritaekonomi\%0Abisnis/d-4902563/\%0Adi-depan-dpr-mentan-ngeluhekspor-\%0Aimpor-panganterganggucorona

Kata Data. (2020a). BPS: Virus Corona Sebabkan Ekspor dan Impor Indonesia- Tiongkok Turun. Retrieved May 3, 2020, from https://katadata.co.id/\%0Aberita/2020/02/17/bpsviruscorona-\%0Asebabkan-ekspor-danimpor-\%0Aindonesia-tiongkok-turun

Kata Data. (2020b). Skenario Terburuk Dampak Corona. Retrieved April 18, 2020, from https://katadata.co.id/berita/2020/04/01/sri-mulyani-skenario-terburuk-dampak-coronaekonomi-ri-minus-04

Kementerian Keuangan RI. (2020a). Menjaga Ekonomi Indonesia Terhadap Dampak Negatif Pandemik COVID-19. Jakarta.

Kementerian Keuangan RI. (2020b). Pemerintah Ambil Langkah Mitigasi Dampak Ekonomi dari Penyebaran Virus Corona. Jakarta. 
Kementrian Kesehatan RI. (2020a). Pedoman Pencegahan dan Pengendalian Coronavirus Disease (COVID-19). Jakarta.

Kementrian Kesehatan RI. (2020b). Situasi Terkini Perkembangan Coronavirus Disease (COVID-19) 25 April 2020. Retrieved April 26, 2020, from https://covid19.kemkes.go.id/situasi-infeksi-emerging/info-corona-virus/situasi-terkiniperkembangan-coronavirus-disease-covid-19-18-april-2020/

Martinelli, I., et al. (2019). Community Economic Development Prospect Based on Wakaf Funds. Budapest International Research and Critics Institute-Journal (BIRCI-Journal, 409-423.

Manulife Investment Management. (2020). COVID-19: Disruption, not Destruction. Jakarta.

Media Indonesia. (2020). Mengantisipasi Dampak Covid-19 ke Perekonomian Nasional. Retrieved April 18, 2020, from https://m.mediaindonesia.com/read/detail/296853mengantisipasi-dampak-covid-19-ke-perekonomian-nasional

Santoso, Y. I. (2020). Ini Delapan Dampak Negatif Bagi Perekonomian Indonesia Akibat Virus Corona. Retrieved May 13, 2020, from Kontan.co.id website: https://kontan.co.id/news/ini-delapan-dampak-negatif-bagi-perekonomian-indoneisaakibat-wabah-virus-corona

Surabaya Net. (2020). Dampak Covid19 Terhadap Ekonomi Global. Retrieved April 18, 2020, from https://www.suarasurabaya.net/ekonomibisnis/2020/dampak-covid-19terhadap-ekonomi-global-2020/?amp

Tribunnews. (2020). Dampak Virus Corona, Jumlah Turis China di Bali Terus Menurun. Retrieved May 3, 2020, from https://www.tribunnews.com/\%0Atravel/2020/02/14/dampakvirus-\%0Acorona-jumlahturis-chinadi-\%0Abali-terus-menurun

Wollie, G. (2018). The Relationship between Inflation and Economic Growth in Ethiopia. Budapest International Research and Critics Institute-Journal (BIRCI-Journal), 264271. 